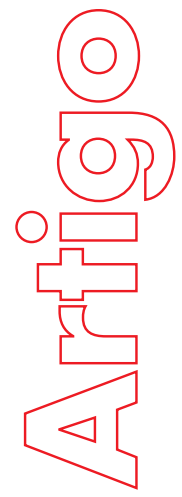

\title{
GOEGRAPHICAL REPRESENTATION OF SPATIAL PLANNING: A SURVEY OF SIX STRATEGIC ENVIRONMENTAL ASSESSMENTS (SEA) OF TRANSPORTATION PLANS IN LATIN AMERICA.
}

\section{Rafael Sanzio Araújo dos Anjos \\ Alessandro Aveni}

p. $147-174$

Como citar este artigo:

AVENI, A., Rafael Sanzio Araújo dos Anjos. GOEGRAPHICAL REPRESENTATION OF SPATIAL PLANNING: A SURVEY OF SIX STRATEGIC ENVIRONMENTAL ASSESSMENTS (SEA) OF TRANSPORTATION PLANS IN LATIN AMERICA.

Eletronic Magazine: Time - Technical - Territory, v.3, n.1 (2012), p. 147:170 ISSN: $2177-4366$

available in:

http://inseer.ibict.br/ciga/index.php/ciga/article/viewFile/99/70

$$
\mathrm{T}-\mathrm{T}-\mathrm{T}
$$

Eletronic Magazine: Time - Technical - Territory, V.3, N.1 (2012), 147:174 ISSN: $2177-4366$
Este obra está licenciado com uma Licença Crea tive Commons Atribuição-NãoComercial 4.0 Internacional. 


\title{
GOEGRAPHICAL REPRESENTATION OF SPATIAL PLANNING: A SURVEY OF SIX STRATEGIC ENVIRONMENTAL ASSESSMENTS (SEA) OF TRANSPORTATION PLANS IN LATIN AMERICA.
}

\author{
Alessandro Aveni \\ Email:Alessandro@unb.br \\ Mestre em Geografia \\ Universidade de Brasília UNB - Brasília \\ Rafael Sanzio Araújo dos Anjos \\ Geógrafo, Doutor em Informações Espaciais (POLIUSP-BR/IRD-FR), \\ Pós-Doutoramento em Cartografia Étnica (MRAC-BE). \\ Professor Associado do Depto. de Geografia da UnB. \\ E-mail:cartografia@unb.br
}

\begin{abstract}
This study examines the representation of space in the Territory Planning (PDT) in the activity of transport with a focus space in Latin America and Brazil, as is assessed by six Strategic Environmental Assessment (SEA) reports. Among these six, two refer to Brazil, two in Bolivia, one in Chile and Peru. The objective of this work is to evaluate the representations of geographic space (GS) in Strategic Environmental Assessments Plans Planning of Transport Activity. This is justified because the concept of territorial planning is changing in his speech, in its meaning, which introduces new challenges. The analysis technique is developed as a qualitative and mixed evaluation scheme based on Fischer, Healey and basic concepts of cartography studies. The result shows a general weakness of the representation of geographic space and cartographic technique of planning. That affects the information published and, at the end, the planning process. In addition to the techniques of planning, correct implementation of sustainability assessment processes with the use of Strategic Environmental Assessment and cartographic representations, it is imperative to reflect methodological advance before the plans that involve a strategic assessment of the space, its representation and its use.
\end{abstract}

Keywords: Geographic Area. Strategic Environmental Assessment. Planning of the Territory. 
RESUMO: O presente estudo analisa a representação do espaço no Planejamento do Território (PdT) na atividade de transportes com enfoque espacial na América Latina e no Brasil, consoante é avaliado por meio de seis relatórios de Avaliação Ambiental Estratégica (AAE). Destes seis relatórios, dois referem-se ao Brasil, dois à Bolívia, um ao Chile e um ao Peru. $\mathrm{O}$ objetivo desta pesquisa é avaliar as representações do espaço geográfico (EG) nas Avaliações Ambientais Estratégicas de Planos do Território da Atividade de Transportes. Esta análise se justifica em razão de que o conceito de planejamento territorial está sofrendo mutações seja no seu discurso, seja no seu significado, o que introduz novos desafios. A técnica de análise desenvolveu-se com avaliação qualitativa com base em esquemas de estudos dos autores Fischer e Healey e de conceitos básicos de cartografia. O resultado da pesquisa mostra em geral uma fraqueza no discurso de planejamento a respeito da representação do espaço geográfico e na técnica cartográfica que afeta a informação publicada e no final o processo de planejamento. Além das técnicas de planejamento, da correta execução dos processos de avaliação de sustentabilidade com o uso da Avaliação Ambiental Estratégica e de representações cartográficas, torna-se imperioso fazer uma reflexão metodológica prévia antes dos planos que envolvem uma avaliação estratégica do espaço, da sua representação e do seu uso.

Palavras-chave: Espaço Geográfico. Avaliação Ambiental Estratégica. Planejamento do Território.

RÉSUMÉ: Cette étude analyse la représentation de l'espace dans l'Aménagement du Territoire (AT) dans l'activité de transport avec une attention spatiale en Amérique latine et au Brésil, évaluée au moyen de six rapports d'Èvaluation Environnementale Stratégique (EES). Parmi ces six rapports, deux reportent au Brésil, deux a Bolivie, l'un au Chili et une au Pérou. L'objectif de cette recherche est d'évaluer les représentations de l'espace géographique (EG) dans les évaluations environnementales stratégiques des plans de planification des transports. Cette analyse est justifiée par le fait que le concept de l'Aménagement territoriale est-il en mutation dans son discours, e dans son sens, ce qui introduit de nouveaux défis. La technique d'analyse a eté mis au point avec l'évaluation qualitative basée sur des études des auteurs l'Fischer et Healey et sur des concepts de base de la cartographie. Le résultat de la recherche affiche une faiblesse dans le discours global de planification de la représentation de l'espace géographique et 
technique cartographique qui affecte les informations publiées et, o final, la procédure d’ ámenagement elle même. Au-delá des techniques de ámenagement, de mise en œuvre correcte des procédures d'évaluation de durabilité avec l'utilisation de l'évaluation environnementale stratégique et des représentations cartographiques, il est impératif de tenir compte en avance da méthodologie avant de la production des plans qui impliquent une évaluation stratégique de l'espace, sa représentation et son utilisation.

Mots-clés: Espace géographique. Évaluation environnementale stratégique. l'Aménagement du Territoire.

\section{Introduction}

The space is past and present actions together, already frozen in objects (SANTOS, 1996). We define and plan future actions cause and effect in the territory, given that they do not yet have real effects, but has an effect, put into budgets and reports, the categorizations and representations of society. The planning process of the territory (PDT) is a social practice that sets new representations in Geographic Space (GS) among the actions thus considered "frozen in objects."

The spaces are those which have send a set of conditions to decide on elsewhere. The PDT is among the causes of this dynamic in public and private types. Planning the public domain, which is what matters in this work, means Policies, Plans, Programs and Projects defined in law, originated and practiced for the state and public institutions which impose their actions in space. The Strategic Environmental Assessment (SEA) of Policies, Plans and Programmes (PPP), translates into a report, evaluates the strategies and actions contained in the PPP to reach the territory noting in particular the environmental impacts.

The objective of this article is to evaluate the representation of geographic space in SEA's Transport Plans, a set of PDT. This is justified because the present work, an analysis of representations of space in reports of SEA and transport planning, is a research activity underdeveloped by geography. The analysis of Geographical Space Reports of SEA Policy, Plans and Public Programs, can also be used to clarify the methodological discussion on Planning and Space Planning. The basic data of the 
research are reports of SEA of Transport Plans between 1995 and 2010 in Latin America.

The work is structured in three sections as follows: the first describes the Territorial Planning (PDT) and Strategic Environmental Assessment (SEA) and covers the geographical concepts of space, nature, environment and transport functions in space. It also points out the importance of cartography in the representation of space. A second section discusses the analysis performed for the geographical area of Latin America and particularly Brazil. It will be shown the representation of space in the SEA and create a characterization of the phenomenon, and comment the results focusing on the Brazilian case. A last section is devoted to conclusions.

\section{Planning and Strategic Environmental Assessment Some References}

\subsection{Planning}

The territory representation and management are a powerful means through the organization of space, enabling the existence and reproduction of society as a whole. The management of the territory, on the other hand, has "a history that translates into social workers and distinct spatial practices, historically variable" (CORRÊA, 1992, p. 115).

Recently in Brazil, the Ministry of Planning, Budget and Management (MP), aware of the interactions between process development and space, has targeted efforts to introduce this concept in the Multi-annual Plan (PPA) Federal Government's main tool for

action planning government.

To further advance the implementation of territorial planning in Brazil, in 2006 the Ministry, through the Department of Planning and Strategic Investments - SPI has developed a comprehensive study about the development process of the Brazilian territory, in order to support the development of the PPA 2008 -2011. This study, called "Study Approach to Subsidize the Territorial Dimension of the PPA 2008-2011 National Development Planning and Long-Term Government", or, synthetically, "Study of Territorial Planning," aims not only to analyze the overlap between development and deep territory, but also generate, from that analysis, a coordinated set of investments that could cause a change in the current configuration of the national territory. 
Characterized by a high spatial concentration of population and economic terms in the coastal region and central southern country From this point of view, it can be stated that the "Study of Physical Planning has the assumption that the investments of the Government, particularly the Federal Government, are determinants of a new economic geography

of

Brazil.

In fact there are different levels of disagreement about planning purposes due to the degree of concentration of power exists. Disagreements generate conflicts over land use in the tuning fork and are ways of looking at the existing power in places. Power is an objectification of the political forces conflict in a territory. This is formed from space, is the result of an action conducted by an actor who performs a program (syntagmatic actor) at any level. He appropriating a space, realizes or performs an abstract representation. One can say in agreement with Raffestin (1993) that the actor "produce territory" or "produce space". The PDT is this, a way to govern the territory, a syntagmatic action of an actors, a form of power production, which develops and implements a set of concepts, processes and tools. In this, people are the most critical part.

In a post-industrial society is there any difference between the place of decision and the place of action. This feature leads to the problem that the flow of decisions, which reflect the decision-making powers, are in fact extra-territorial in the sense that no longer exists, these post-industrial societies, a defined hierarchy between places and government of the territory (DE MASI, 2003). Therefore, the complexity of strategic choices in PDT depends not just about getting a role of central government, but on various levels of effective control of the territory (or supra-local and local) and how the actors and agents compete for land use interpret the actions planned by the central government. At last it depends also on the spatial representations of geographical elements relationship. A state monopoly on information and therefore its influence in decision-making is completely compromised, so is the concept of territory, ie. the domain of the state territory to be compromised. Therefore, planning decisions and environmental impacts are necessarily aware of places, local authorities and their agents. 
The nature and the environment representations, in turn, pass through the interaction between the units of the natural landscape and the polygons of human intervention. The environmental problem in PDT enters the environment in the concept of sustainability. The PDT must be committed to this goal, which is an interpretation of future space post-industrial society.

Sustainability and planning are complementary in the sense that sustainability is a strategy of spatial planning. Sustainability, however, need planning strengthening, so it is important for planners to define the dynamics and effects of common resources concerning a participatory process and network, and define what is local zoning control (JEPSON, 2001) .

However is necessary to put on the planning agenda the following issues: spatial differences between the background and the actuators of the plans, a different use of space by men, new social relations and new spaces of relationship; space emergency regional and local emergency cultural and political pressures in the planning, the emergence of local knowledge in territorial politics. These issues focus on rethinking the relationship between territory planning and financial planning, rethinking the hierarchy of planning levels of the territory by placing the region as another actor to rethink the role of society in the planning process, not only with the participation.

The present paper, based on considerations of this section, intends to consider the planning of the territory as a dialogue and information. In other words communication and information play a dominant role in planning. P. Healey (1997, p.233) argues that to understand the dilemma of planning in modern society, it should be committed to the democratic process to promote social justice and a sustainable environment. The administrative and technical mechanisms intended and designed to achieve these goals are based on a strict rationalism and dominant. The criticism also reflects the arguments for and against the plan that are in the literature of urban planning in England. Healey follows the dialectical position of Habermans (1986) who argues that two spheres that coexist in society: the first is the system, ie, a "reproduction aterial" governed by instrumental rationality (adaptation of means to ends), incorporated into the hierarchical relationships (political power) and exchange (economics), the second is 
the life-world, ie is the sphere of 'symbolic play' of language networks of meanings that make up particular world view, they are referring to the facts goals, social norms or the subjective contents. In this interpretation, Habermans (1986) also conceives of communicative rationality and communicative action, ie, free communication, and critical, as an alternative to instrumental reason and the overcoming of Enlightenment reason that masks domination. However is Giddens (1984) who deepens and who is dealing with the interaction continuance in frame construction and the world of life (HEALEY, 1997).

So Healey (1997) treats the problem of planning as a point of view of the "communication" paradigm using the Giddens and Habermans social theories. The author conceives using a dynamic meta language and critiques the theoretical possibility of planning in line with the current requirements of the post-industrial society. Planning becomes dialectic, a communicative action and government and she marries it with a possibility of network communication, wherein there are several different actors and social movements that relate to the same and in different places of the territory and outside it.

Therefore the proposal planning practice must set limits and rules that allow it to be recursive but also reflective and inter subjective, that is: dialog (Healey, 1997). This ultimately, is the hypothesis of Mannheim (1984 p.115) that social knowledge is no longer a search between rational and irrational, but a set of empirical ontology and value judgments.

\subsection{Strategic}

Assessment

The transport plans' environmental impact assessment can be implemented with the use of Strategic Environmental Assessments reports, the basic documents of this research. The simplest way to define SEA is "evaluating the environmental impacts of a policy, plan or program (PPP)." The present SEA scholar definitions are divided between those associated with the concept of environmental impact assessment of projects (and THERIVEL and PARTITÁDARIO, 1996) and those that supported the concept of 
environmental management and sustainable development (Sadler and VERHEEM, 1996, THERIVEL, 2004).

According to the Brazilian Ministry of Environment, the Strategic Environmental Assessment (SEA) is an instrument of environmental policy that aims to assist in advance, decision makers in the process of identifying and assessing the impacts and effects, maximizing the positive and minimizing the negative, given that a strategic decision - regarding the implementation of a policy, plan or program - could trigger in the environment and sustainable use of natural resources, whatever the planning instance.

The benefits to be expected as a result of application of SEA are mainly: - comprehensive overview of the environmental implications of the implementation of policies, plans and government programs (PPP), whether the relevant activity development or applied to a region's security and environmental issues are adequately addressed in these different levels of government of the territory; - facilitating the linking of environmentally structured actions in the territory; - policy and integrated planning and environmentally sustainable; - assessment of the likely impacts of actions and projects necessary for the implementation of policies and plans and programs that are being evaluated, and - provide a better context for the assessment of cumulative environmental impacts potentially generated by those projects with a process of consultation and public participation.

Egler (2001), the most important Brazilian author of the subject, however, stressed that the discussion of SEA is still unclear about the methodological aspects. One group of problems, as mentioned, is certainly the path dependence, ie. the direction that was printed in the legislation regarding the territory government and planning process that is difficult to be modified in the short term. It can be summarized in the words of Egler (2008) that the characteristics of SEA, the look of sustainability as a process that goes into a strategy based on the vision of the future SEA (ie. MMA in Brazil) as the integration and greed inclusion of environmental aspects in PDT (called Objective-led). The other is to solve problems 
R. Therivel and others in Europe) as a process more flexible in the direction of sustainability. The SEA is part of sustainability reports that are part of an EP (called Baseline-led).

Another problem detected in Brazil, is the vision or a strategy planning in the PDT. The Ministry of Planning, Budget and Management (MP), aware of the interactions between EG and development process, has directed its efforts to introduce this concept in the Multi-Annual Plan (PPA) of the Federal Government. , However, is far from defining a position of sustainable comprehensive planning. Egler (2008) again reiterates that the greatest difficulty able to delay the implementation of SEA in Brazil lies in the political context that involves the planning activity.

Make advance the goals of a public policy, plan or program (PPP) is not a usual procedure of those who are responsible for preparing these documents. Usually the PPP are maintained in a limited scope in order to avoid adverse reactions or due to the sensitive nature of some of them (economic plans are good examples of a sensitive area).

\subsection{Geographical space}

Here we use a definition of space that belongs more to a neo-Marxist critical theory. But there are different concepts of space a sense of geographical space is neutral and neck depends on the social culture that uses it. Santos (1997) points out that space is an instance of the society. In its definition instance, it contains and is contained in other instances. Thus, the essence of space is social (and political). We parallel the one hand the set of objects distributed over a geographic area, its geography or space and how these objects are given to our eyes visible in its continuity (the landscape), on the other side, which gives life to these objects (active principle), ie, all social processes representative of a society at a given time (SANTOS, 1997). 

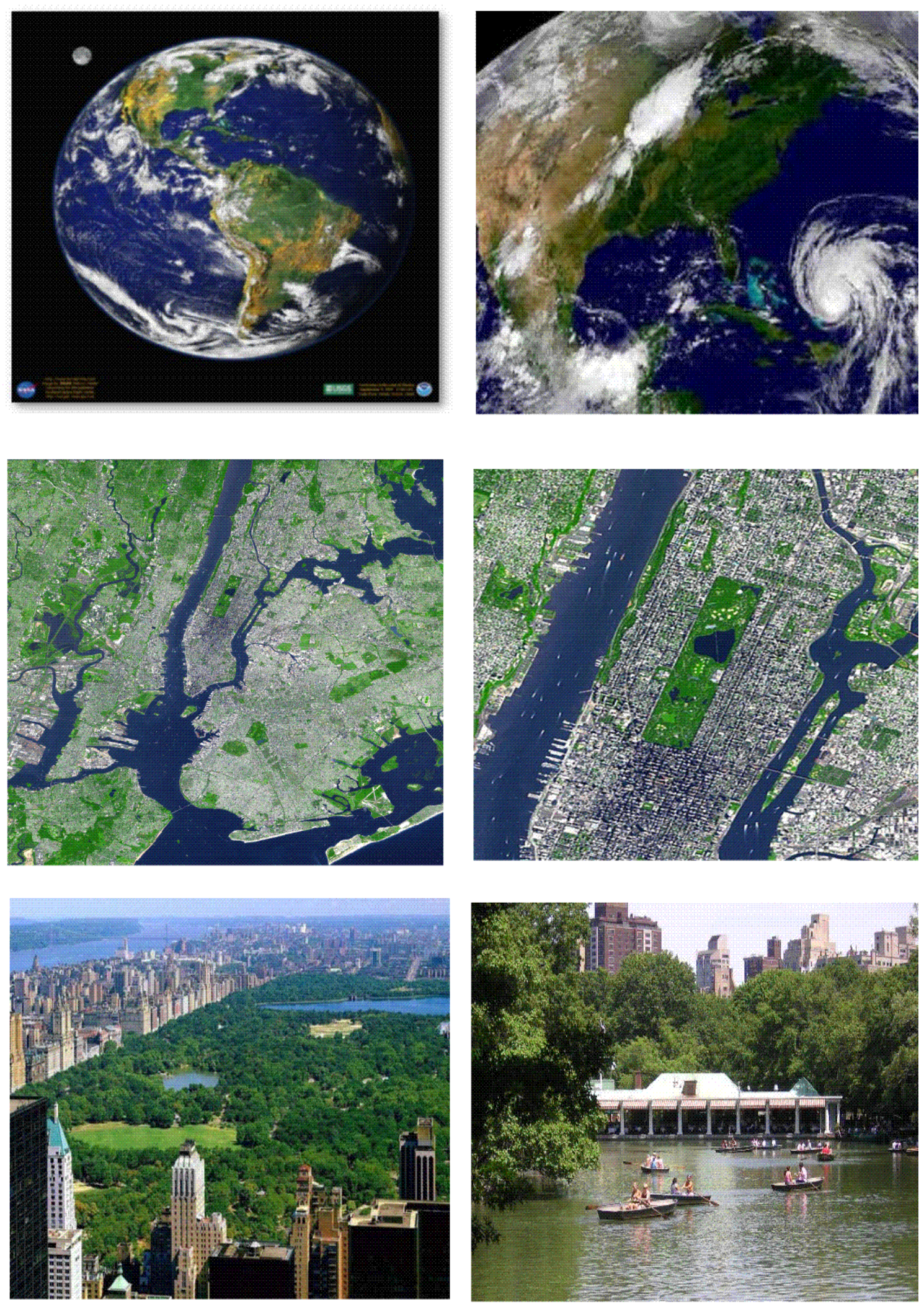

Figure 1 - Geographis space representation: from global to local.

Font: Atlante Cartográfico Satellitare.De Agostini - Itália Edição 2000 
These processes are resolved as that are carried out through forms. These are initially geographical and then take a territorial expression. The fractions containing geographical forms of the social, that are not just forms, but forms, content, because they change as the social movement that gives them their fractions of the social whole. The action is inherent in the conditioning function and it is in the shape that contains it. So the whole process establishes a meaning only when embodied. However, Santos (1997) explains that is a space that contains the category, or is a category of analytical entirety.

The space is socially produced and a structure created is a subject-object of an interpretation of space, so it is not necessary to divide the space of society because it is necessary rules for shipbuilding and separate. Then, in the present paper we share the sayings of Surtegaray (2001) on the concept of GS as "one and multiple". Space is the broader concept, a whole whose meaning is one of the most abstract among the Geography. The geographical space express different levels of abstraction and, consequently, different operational possibilities. (SUERTEGARAY 2001)

\subsection{Nature and Environment}

Nowadays we need to integrate the concept of GS in the planning of the territory with emerging concepts such as sustainability. Sustainability is a concept connected to Nature and the Environment. The use of Environment in place of GS involves looking at a more linked to concepts of value of natural and anthropogenic systems. Regarding the GS, nature takes meanings of "natural resources, energy and economic value." According to L. C. Cidade (2001) our view of nature derives from paradigms set the course of centuries. For the author, the modern system, the reason, the analytical method and subject-object separation have been considered pillars of countless scientific achievements. Facing the current challenges, particularly in the description of nature and society, the society-nature theme was always present in the discourse of geography.

The very Nature meaning can be understood as building and construction of social processes, since the current pattern, it cannot be understood so pure (ecosystem), 
separated from its subject, the man. It was the German scientist Ernst Haeckel in 1869, who first used the word Nature to order the study of relationships between living beings and the environment habitat. Using Nature means focuses on contemporary ecological knowledge area. This provides the criteria of the scientific study of the distribution and abundance of living organisms and the interactions that determine them. Therefore, in the current work Space is Nature and Nature is Space, however, the concept of nature that emphasizes the aspect of the ecosystem as a source of services essential to the survival of man and his empirical human perception. Thus, in defining the Nature we configure and highlight critical aspects or fundamental to life on Earth and thus the physical rather than psychological and social. It should be noted with the concept of the nature of "value for living" space in particular focused on the value of energy and

balance.

Therefore the SEA and the PDT is used instead of Nature, the concept of the Environment. Environment is another social representation of space and nature. The term began to be used politically in 1972 when it was held in Stockholm in Sweden, the First World Conference on the Environment. This was the first milestone of meetings involving representatives of various States to the debate on environmental issues and nature conservation. During the 80 years was resumed discussion of the environment against the economic development. Through these international discussions, the concept of the Environment regarding the nature and GS took a much more apparent characteristic of "socio-political value".

This affected the laws of various nations, for example, in the Federal Constitution of Brazil in 1988 is set Everyone is entitled to an ecologically balanced environment, and the common use and essential to a healthy quality of life, imposing on the government and the community the duty to defend and preserve it for present and future generations.

What reflects a principle of the United Nations, where: Man has the fundamental right to liberty, equality, and to enjoy adequate living conditions, in an environment of quality that permits a life of dignity and well-being and is the carrier's solemn obligation to protect and improve the environment environment 
for present and future generations. (UNITED NATIONS

The Environment, considered in the present paper, has social, economic and political process in PDT and Transport Plans. A resource or a territory (parts of Nature) has no value unless it is inserted in the terms of use and, in particular in this work, in term of transport activity. Environment is part of nature that assumes value as a natural resource (not yet exploited), but is also part of nature manufactured (modified work) to man.

\subsection{Transport flows and fixed assets.}

In case of transport activity should also be pointed out the difference between concepts of transport flows in space and fixed assets. Clozier (1963) says that geography, that deals with transportation, focuses on roles and relationships of communication proposing the science of Geography as spatial interaction and communication.

Already in the 80 Rafferstin, developed in geography the difference between movement and communication, and Santos and Silveira (2001) speak of "geography of movement" or mobility once she has the central problems the movement of goods, services and capital (geography international trade, geographic markets and businesses, geographic flows of capital); forms and transport networks (road, rail, waterways, seas and oceans, air), humans and their spatial mobility (taxonomy of mobility, migration, "spillovers" technology, tourism); information and networks (media, information flows, networks, nodes).

Transport is, however, a space-territory relationship with important features and unique to the space. The functions of transport become important to explain their plans and environmental assessments. The structure of space necessarily refers to physical and social base, given that, for example, the distance is regarded as the movement functional distance (ie, the function of the relationships between different points in space that can be achieved for people). The spatial interaction between these forms leads to set the distances depending on the relationship between physical and virtual objects.

Thus, the interest is even an isometric analysis (ratio of distance from the same function) which is different from the physical distance, ie. $\mathrm{km}$. The speed (and time) is part of the equation that defines the communication and "broad sense", integration, 
understood as a function of mobility. There is thus the actual speed, or useful commercial, and the average.

Transport activities attribute to space features some social functions. The functions are the objectives to the satisfaction of a user's needs and movement of goods, services and capital. The mobility, is relevant in the way of looking at the movement and the concepts of migration and urban mobility and extra-urban, or semi-nomadic life inside (we must not lose the concept of international migration), tourist mobility.

\subsection{Cartography}

For IBGE (IBGE, 1998), etymologically speaking the word cartography - description of space - was introduced in 1839, the second Viscount of Santarem, Francisco Manoel de Barros e Souza de Mesquita de Macedo Leitão (1791-1856).

The concept of Cartography, now accepted without major challenges, was established in 1966 by the International Cartographic Association (ICA), and later ratified by UNESCO, the same year: "The cartography is presented as a set of studies and scientific operations, technical and artistic, based on the results of direct observation or examination of documents, turn to the preparation of maps, charts and other forms of expression or representation of objects, elements, phenomena and physical and socioeconomic environments, as well as its utilization. "

The IBGE explains that the cartographic representation can exist as a globe, map, chart, plan or image. For any representation you must set its scale. Scale is defined as the ratio between the size of a drawing line and their counterparts. The preparation of a letter requires first of all, the establishment of a method, whereby each point on the surface of the earth corresponds to a point on the map, and vice versa. We can also say that according to IBGE (IBGE, 1998) that all representations of curved surfaces in a plan involving "extensions" or "contractions" that result in distortions or "tears." The construction of a projection system will be chosen so that the card will have properties which meet the objectives required for its use.

The nature of representation in the reports of the Strategic Environmental Assessment of the current study is to represent geographic scales of 1:1,000,000 and smaller 
$(1: 2,500,000,1: 5,000,0001: 30.000 .000$ up). In this type of card details planimetric and altimetric are generalized, which offer accuracy in accordance with the scale of publication.

There is also a use of thematic maps. These are the letters, maps or plans at any scale, intended for a specific topic, the research necessary to socioeconomic, natural resources and environmental studies.

Being a map or chart representation, a single sheet of paper from the surface in reduced dimensions, you must associate the elements of symbols and conventions. The symbols that include cartographic conventions, meeting the requirements of technical drawing and photographic reproduction, represent in a more expressive, the different terrain and topographic objects in general.

Through graphical and thematic maps it can be represented an activity of transport and spatial relationship between objects as a territory, region and environment. So the way to represent the space exists in SEA mostly with thematic maps. The purpose of this representation is to provide, with the aid of symbols and / or qualitative quantitative arranged on a basis of reference drawn from maps and topographical maps, information about a particular topic or phenomenon that is present or acts in the territory mapped.

One of the first authors to present the map as a standard model in cartography, was Borad (1967, apud SIMIELLI, 1986) that defined the map as a model of reality, made from a scientific method of investigation. According to Taylor (1994), the reflection of the more modern theory of modeling is the introduction of the technology of geographic information systems - GIS, as a result, on the one hand, the intensive use of mathematical and statistical methods in working with many variables and, on the other of all technological and computing, especially graphics programs.

Bertin (1967) was the first author who systematized the graphic language as a system of graphic symbols with meaning and significant with respect to graphic semiology. He considered as meaning the relationship between the data to be represented, noting that these relations can be similarity / diversity of order or proportionality. Then the relations must be transcribed on the map with visual variables that represent the exact 
relationship between the data to be represented. The significant variables are the following visual: size, value, texture, color, orientation and shape.

\section{Techniques of data processing and study results}

The technique used in the work to show representations of space in the SEA try to find empirical relationships of cause and effect, for lack of consolidated methodologies for analyzing the specific problem of the research. The technical analysis is here divided into three steps: Audit of procedures for SEA Analysis "Rhetoric" (or discourse) inside the SEA, the SEA Cartographic Analysis.

Audit. Below Tables 1 and 2 show the description of the proposal evaluation audit Fischer formal review. The basic scheme of assessment is in accordance with Annex I of the book cited by the same author (FISCHER 2007, p.155). The review process (Table 1) is based on a qualitative analysis (the degree of quality) based on assessments of a (hit) and G (not reached) for each step of analysis.

The questions to assess the SEA are divided into six steps and each step there are questions to be answered to assess the degree of achievement of objectives. The questions for this qualitative assessment are shown in Table 2. The evaluation process takes place answering the questions in sequence. The answers to the questions have resulted in the level of quality, ie, what value was reached in which the goal of the question, the value is always a (hit) and the maximum value of $G$ (not reached) the least. Results, averaged for each question infers the final qualitative evaluation.

Table 1 - Strategic Environmental Assesment (SEA) audinting: values.

A Fully achieved

B Achieved with minor omissions

C Achieved with omissions and inadequacies

D Not achieved with omissions and inadequacies

E Not Satisfactory with relevant omissions and faults

F Very unsatisfactory important parts missing and weakly developed

G Not attempted completely 
$\mathrm{n}$ / a not applicable

? unclear

Source: Fischer (2007:155).

Table 2 - Strategic Environmental Assesment (SEA) auditing: process.

\section{DESCRIPTION OF THE PROGRAM AND DATABASE}

highlights the objectives

emphasizes the interaction with other PPPP

explains how SEA was carried out

describes how it is integrated into the decision process to the PPP

describes the problems of other integrated assesment

make the information relevant to the situation ex ante

poses significant problems

places information about the goals of protecting the environment

2. IDENTIFICATION AND EVALUATION OF THE CRITICAL ISSUES AND OPTIONS

considers the objectives and geographical scope of the PPP

lists the problems considered

describes how the goals were identified

describes key information *

describes the issues that must be defined with assessments

explains evaluation methods which were used for information

\section{DETERMINATION OF IMPACTS}

identifies a system PPP

Identifies the value and vulnerability of the area

identifies the landscape

identifies the effects of the environment

identifies the side effects

trans identifies border effects (Area)

identifies risks to human health

identifies the geographic area and population affected

\section{PROCESS OF PUBLIC DISCUSSION}

describes the level of governance

describes how the summary of the assessment was made available for those who e'afetado

confirms the results of the incorporated thread shape

\section{REPORTING}

sections and includes a report

poses difficulties and uncertainties encountered in the process

is defined as a choice of course as the process to minimize

impacts on the choice itself (participatory process, and alternative comparison purposes) 
6. RECOMMENDATIONS AND DESCRIPTION OF THE CHOSEN ALTERNATIVE AND MONITORING

presents the choices and motivations

puts the information on how to avoid impacts and what measures to mitigate impacts

poses as monitor any effects not predictable

describes how monitoring

Explains how the monitoring will be

explains how the monitoring is done

Source: Fischer (2007:155). Adaptation: Alessandro Aveni

Rhetorical Analysis. The second step of analysis used in this study show the discursive representations of geographic space in the SEA of transport plans. The first analysis ensures uniformity, consistency of process and process elements dealing with the environment and thus the geographical space. This second part of the analysis has been developed based on a model of P. Healey (2004) she had applied to an analysis of three cases of European planning processes.

Table 3 - Healey Criteria for qualitative (rhetorical) analysis.

\begin{tabular}{lll}
\hline Criterion & Essentialist conception & Relational conception \\
\hline $\begin{array}{l}\text { Treatment of scale } \\
\begin{array}{l}\text { Treatment of } \\
\text { position }\end{array}\end{array}$ & Hested hierarchy & Relational reach in different networks \\
\hline Regionalization & $\begin{array}{l}\text { An integrated, } \\
\text { differentiated } \\
\text { physical fabric }\end{array}$ & $\begin{array}{l}\text { Different positions in different networks } \\
\text { multiple networks coexist }\end{array}$ \\
\hline $\begin{array}{l}\text { Materiality and } \\
\text { identity }\end{array}$ & $\begin{array}{l}\text { A material physical future } \\
\text { can be built, meshed with } \\
\text { social relations in an } \\
\text { integrated way }\end{array}$ & $\begin{array}{l}\text { Materialities are co-existent with } \\
\text { conceptions of identity and iconographies } \\
\text { of space/place }\end{array}$ \\
\hline $\begin{array}{l}\text { Concept of } \\
\text { development }\end{array}$ & $\begin{array}{l}\text { An integrated linear } \\
\text { trjactory }\end{array}$ & $\begin{array}{l}\text { Multiple, non-linear, continually emergent } \\
\text { trajectories }\end{array}$ \\
\hline $\begin{array}{l}\text { Representational } \\
\text { form }\end{array}$ & $\begin{array}{l}\text { Material metaphors of } \\
\text { functional integration, } \\
\text { expressed in maps }\end{array}$ & $\begin{array}{l}\text { Metaphors of movement and ambience, } \\
\text { expressed in multiple ways. }\end{array}$ \\
\hline
\end{tabular}

Figure 1 Criteria for evaluating concepts of space and place

International Journal of Urban and Regional Research

(1) Joint Editors and Blackwell Publishing Ltd 2004

Source: Healey (2004:48).

The analysis is based on dialectical vectors that answer the following questions: What is the treatment of geographic scale?; What is the treatment of the place?; If there is regionalization?; If there is an identification of the identity of the place?; What is the concept of development referred to the place?; What form of representation used? 
Table 3 is a schematic explanation of criteria for analysis due to the above questions. It explains for example, treatment of scale seeks to explain whether there is a full explanation of the document system and explanation of spatial hierarchy: spatial networks in which relations. The treatment of the place (location) seeks to explain in the document is a representation of borders and different nodes of a network space.

The planning documents, as a way to represent and build a space form a vocabulary and practice building a new "political space" (HEALEY 2004, p.51). So a search for relationships between SEA and GS through this vocabulary may be relevant for understanding the phenomena.

The analytical work was developed using the same logic of the Healey (2004) review of three cases in Europe and successively is addicted with transport related concepts. A hierarchy of natural objects is therefore evident in SEA at the same time it is evident in the plans. An analysis with the scheme suggested for Healey is consistent with a look of the planning process of dialogue with the problems due to changes in the process of PDT. It is the direct link with additional reports as the SEA, to be part of a single change plan in the territory.

Cartographic Analysis. The cartographic representation is still in need over the more graphic representations of space. According to the procedure used to evaluate the mapping to graphical representations, one must consider the perspective and plan. You should also consider the guidance in relation to terrestrial coordinates scales and projections. The scale is relevant beyond the type (large, medium and small) a qualifying geographic location, regional, national, continental and global. The map representation is done particularly for reference and should put : the author, in particular the sources and forms of implementation. The forms are the main point, the linear and zonal. These forms may be characterized by variables such as size (which translates relations proportions in geometric figures), value (range of shades that ranks), grain (which suggests the order in space), color (visual selection of the objects represented ), orientation (distinguishes objects) and form (the symbols that represent objects and social space).

Table 4 - Criteria for analysis of imaging from space.

\section{Cartographic base}




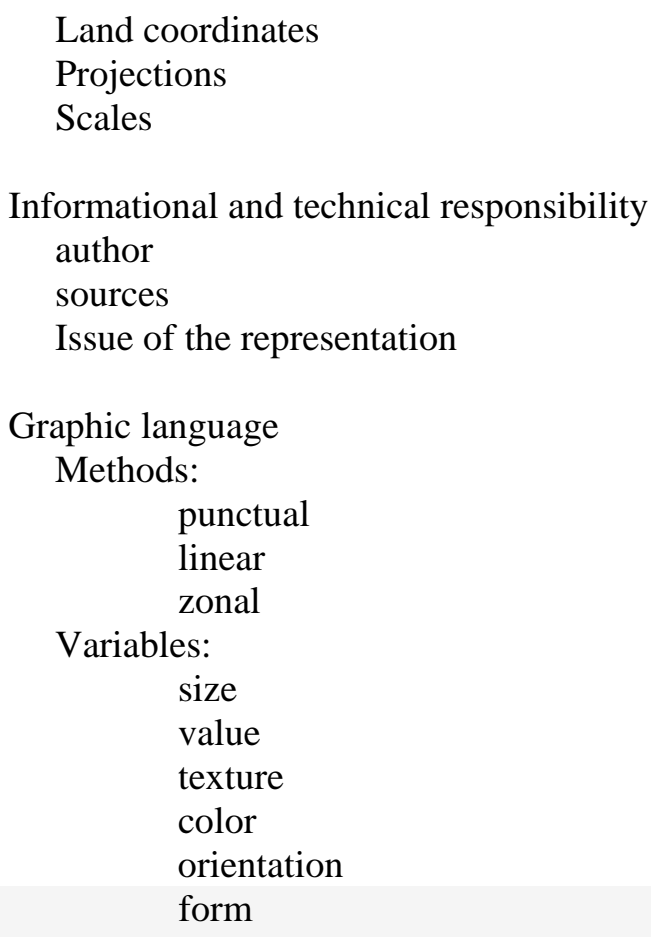

Source: IBGE (1998). Adaptation Alessandro Aveni

In Table 4 are placed on the technical criteria for the patterns of the EAA graphical information of the target survey. With this check list, which uses basic mapping representation, finally it is drawn graphical and symbolic attention in the work. A bad representation is bad information too and does not allow good evaluations and decisions of government space.

Summary of the Research. On applying the three techniques are reached some results. In particular the case stands Brazilians from Minas Gerais to be a good analysis and Brasilia for not being one. From the viewpoint of the speech, the space does not receive much attention in Brasilia and in the case of Minas Gerais, they are focused on the first objective, the need for interventions in the city that do not report much about planning, but as program interventions. In the case of Minas Gerais an attention to indicators that the advisory group wanted to put it as a landmark analysis, is explored. A failure to use a methodology, as reported to Egler (2001) is evident.

As regards the analysis of the reports is Healey weaknesses, in particular with regard to criteria which should be stressed scale flow manager and range of movements (local and regional). Regarding the place one would expect the analysis of spatial mobility, interactions and focus on features for the users of transport. About development it was expected a cost analysis and projections about the future social space. 
However the SEA is an analysis that uses GS. In those reports, there are definitions of scale, distance, space and structure interaction, however, so fragmentary. In particular, in Minas Gerais, a regional analysis is sufficiently developed and the regionalization, however, with loss of information about the identity of the place of the interventions. There is no developed criteria defining and linking regional development plans in relation to municipalities and zoning about decisions on transport. Nevertheless, there are forms of representation and a thematic use of GIS and other mapping techniques, but this does not lead to a complete representation of traffic flows.

Types of transport mobility are analyzed for Minas Gerais cargo and tourism. There is an integrated analysis of the functions assigned to the space, ie goals of satisfying a user's needs and movement of goods, services and capital, forms of transport and communication, spatial mobility of goods, information and people, information and communication space.

In the Minas Gerais SEA, dominates a very positive factor in the risk analysis of impacts of freight transport, however, completely lacking an analysis of different possibilities to change the matrix of transport not only in relation to the modal, but also within the matrix road What is the purpose of analysis. This is strange being that the report aims to make a strategic analysis.

In both reports also there is lack of alternatives analysis and public discussion. The spatial mobility is analyzed in statistical terms but without deep social. The analysis of data likely source of the DNIT is not detailed and well referenced. At the end is a place that does not follow the rules of use of statistical techniques.

In relation to spatial representations, Minas Gerais has an outstanding level cartographic representation, but lack Brasilia, because there is much concern in the report with quantitative data and tables. In relation to consultants, Brasilia, which sought outside ones it comes off as worse. In relation to monitoring in view of integration in the planning process, the legal case of Brasilia stopped analyzes. In the case of Minas Gerais there was no monitoring until the researcher knew the review and a continuation of SEA and its integration in the transport plans of Minas Gerais. 


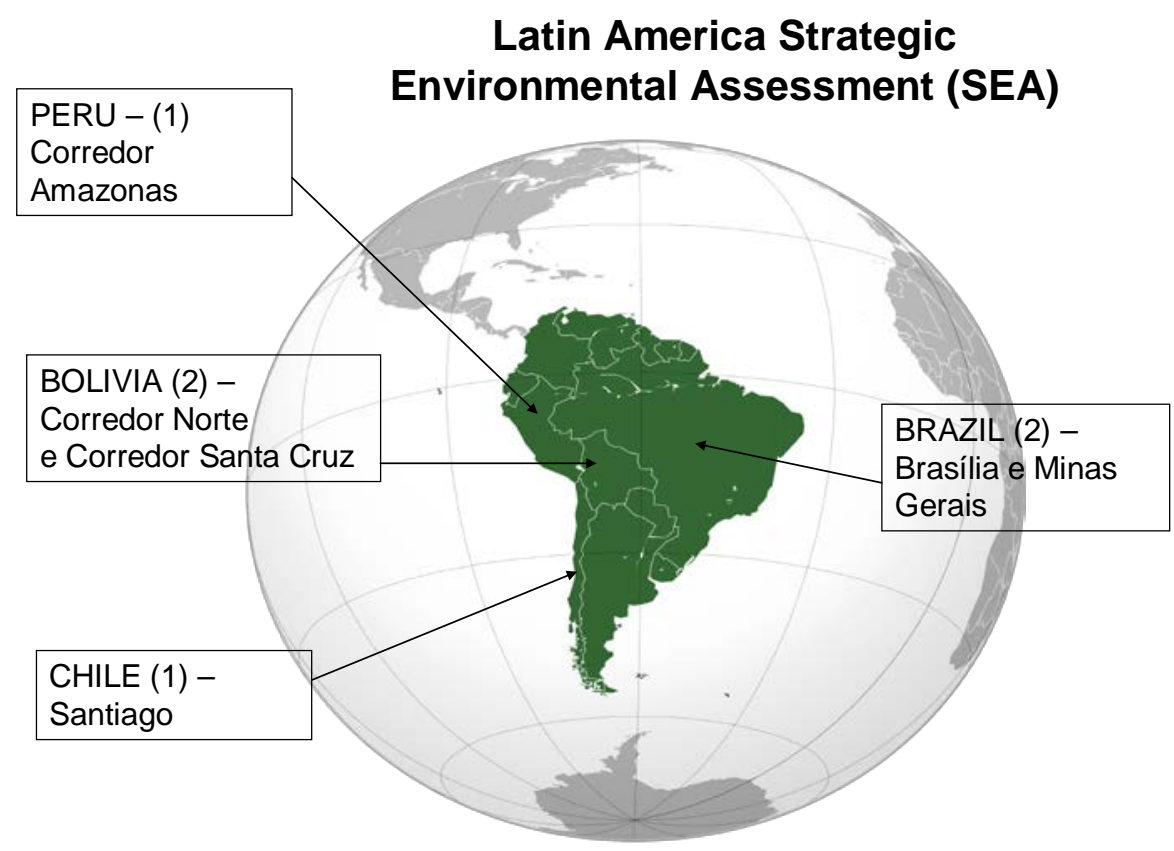

Figure 2 - Strategic Environmental Assessment (SEA) in Latin America.

Source: South_America_(orthographic_projection).svg (ficheiro SVG, de $541 \times 541$ pixels, tamanho: $386 \mathrm{kB}$ ) - Luan - http://creativecommons.org/licenses/by-sa/3.0/. Adaptation: Alessandro Aveni

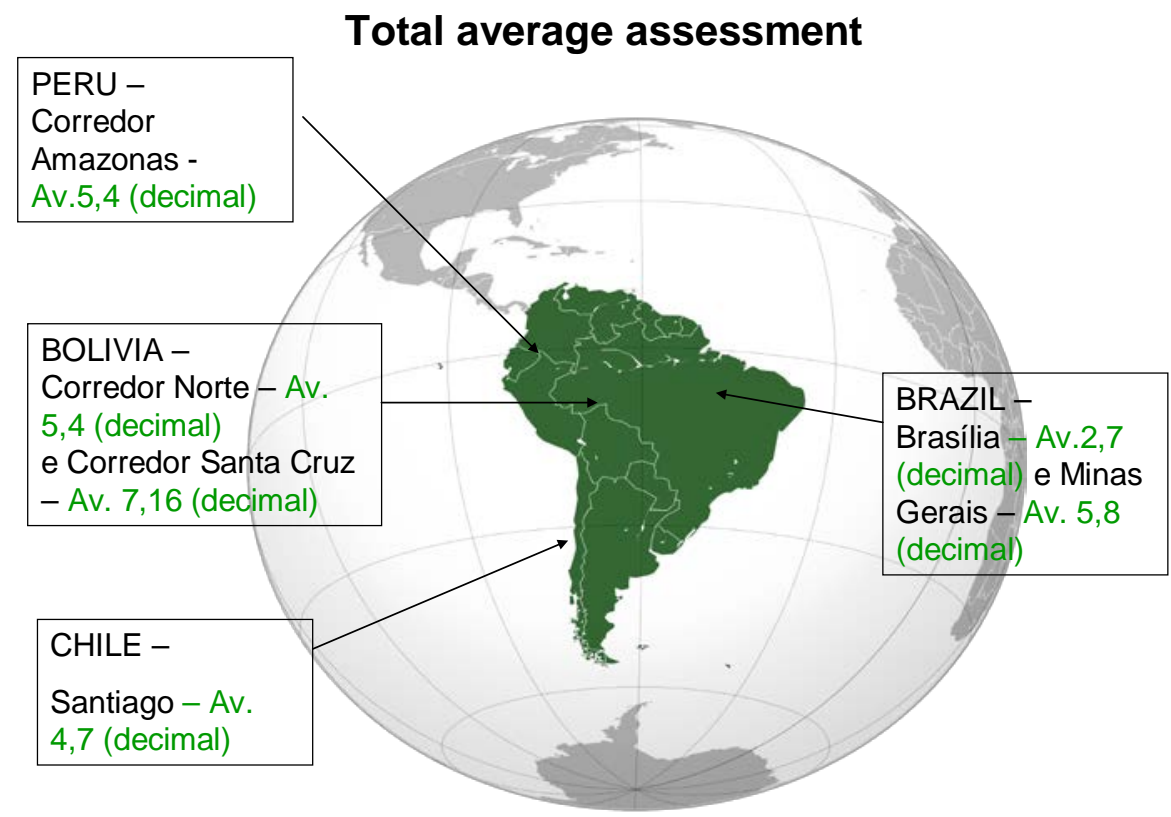

Figure 3 - Results of Strategic Environmental Assessment (SEA) of Transport Plans in Latin America geographical qualitative analyses. 
Source: South_America_ (orthographic_projection). Svg (SVG file, nominally $541 \times 541$ pixels, file size: $386 \mathrm{kB}$ ) - Luan - http://creativecommons.org/licenses/by-sa/3.0/. Adaptation: Alessandro Aveni

\section{Conclusions and recommendations}

One possibility for transport plans SEAs to be integrated into PDT is to address the GS, put it in the speech, using graphical representations as a self-explanatory it is producing space. These SEA reports demonstrate an approach that leads to understand the actions and objects in the territory (climate, water, soil, etc..). But it is done in a separate way which does not allow an integrated view. Such an approach needs, for example, to integrate the common analysis in physical geography that analyzes geosystems, ecosystems and emergy (ie. cost of energy in joule). Such analysis is not addressed in any report.

Thus the desired "integrated spatial" plans and reports by the SEA analysis, is confused with the "integration into a single document from multiple geographic elements of the assessment." To clarify this difference that is not only verbal: in the same document are placed the elements of nature, the social and economic factors and actions and impacts. But this is not "integrate" the elements for a decision space, but put them in the same document. This is set against a matrix of type (causal) two-dimensional and not the multiplicity of dimensions. Lack focus on the concepts that characterize the spatial geographic territory.

In this paper, the term integration, means a complete (ie multiple and polycentric in the same moment in time) assessment of all the elements of GS, which may aid a better understanding and representation for a decision-maker. Therefore, the best representation is not matrix (or two-dimensional), but, one connected to the network and mapping using, for example, the technique SIG and dynamic graphical representation. The links thus should not be represented only as a double cause and effect and no spatial depth, but are multiple and polycentric.

A complete Geographic Space analysis can add value to SEA and the planning of the territory, ie, provide better information for decisions. A failure in representing space is clearly the issue of governance of public space and a power issue. 
The survey of Latin America SEA confirm two issues: a different interpretation of the space is perceived in the plans and evaluations of SEA and the difficulty of integrating SEA in PDT, since it realizes the need for an interpretation of the spatial planning of the territory.

Research has shown the problems of using the space category in the reports of SEA for transport plans, particularly in Latin America and Brazil. There is a failure to use comprehensive, integrated and holistic concept of GS in the reports, even though present fragments of geographical concepts and representations on maps. This result opens the possibility of research on the subject.

It also appears, in the analysis, in relation to the movement and transport that the use of PDT in GS transport is more connected to society and their representations of the fixed assets than the physical characteristics and flows. Thus, the role of transport in space is not well represented because is linked more to structures and less to economic flows. Functions such as leisure (with the exception of tourism), type of travel in relation to age and culture are not addressed in the reports and plans.

To confirm this assessment highlights that the representations of flows are not represented in the SEA and plans or maps, but in tables. This is somewhat surprising, and in relation to transport infrastructure would have been expected a greater use of maps, especially information flows and movement. But considering that these documents have a strong political sense, it is not surprising that the technicians who prepare the SEA are subject to political appointments and tend to distort strategies and analysis techniques with a strong representation of economic and engineering (tables and graphs and matrices).

In many cases, was relevant in the search to a lack of part of the planning process: monitoring. This is particularly the case in Latin America where monitoring is also dependent on donors. By monitoring not only mean a confrontation between prediction and outcome. A good monitoring includes ongoing review of the process of PDT in the logic of Strategic Management of PDT.

At last it must be said that the difficulty is probably on dealing with the geographical space and its representation as a component of decision-making process and recognize 
the usefulness of this in PDT mostly in terms of information and communication. In other words, besides the techniques guidelines, or that can be "transferred" teams with specialists, it is important to work before to plan to define the concepts, categories and symbolic representations to be used (strategies and alternatives) rather than the techniques and the procedures that define SEA of PDT.

The training in use and treatment of the concept of geographical space for those who are working in this area seems to be the pivot change and best improve techniques for the PDT including a rhetorical analysis (discourse) and planning history. Based on this final analysis it is deemed essential to auditing the SEA. An audit with the Fischer audit technique This allows to treat all reports in the same way and know the weaknesses of the process before making comparisons.

Technical analysis of alternatives is essential to a better spatial representation and use of techniques that include the definition of space (physical, social, economic etc.). Some model also can be used for quantitative analysis of alternatives. With these suggestions he is also the indispensable necessity of a better use of imaging techniques. At present, the use of GIS is important to note that there is no excuse in not complete graphical representations. The use of techniques that yield dynamic representations is also required.

For PDT in particular transport planning, the relationship with the environment can be used to discuss alternatives strategic outside the physical environment - society relationship that only highlights aspects of pollution and fossil fuels reduction. For example, function in relation to tourism is often used, but there are not represented neither discursively nor graphically.

\section{REFERENCES}

BERTIN, J. Sémiologie Graphique: les diagrammes, les réseaux, les cartes. Paris:Mounton e Gauthier-Villars, 1967.

BOARD, C. Os mapas como modelos: modelos físicos e de informação in em

Geografia. Coord. Richard J. Chorley e Peter Hagett. São Paulo: EDUSP, 1975. 
DE MASI, D. (org.) A sociedade pós-industrial. 4a ed. São Paulo Senac, 2003.

DALAL CLAYTON B., e SADLER B., Strategic Environmental Assessment: A Sourcebook and Reference Guide to International Experience, Earthscan, Paperback edition, London, 2005.

EGLER, P.G. Perspectivas de uso no Brasil do processo de Avaliação Ambiental Estratégica Eduação e Meio Ambiente, 2001. Disponível em: <http:// www.mct.gov.br/CEE/revista/rev11.htm Acesso em 30/07/2011.

EGLER, P.C.G., Improving the Environmental Impact Assessment Process in Brazil. PhD Thesis the School of Environmental Sciences University of East Anglia, England, 1998.

FISCHER, T.B. Theory and Practise of Strategic Evironmental Assesment, Heartscan, London,2007.

GIDDENS, A. The Constitution of Society: Outline of the Theory of Structuration

Cambridge: Polity Press, 1994.

HARVEY, D. A condição pós-moderna. Uma pesquisa sobre as origens da mudança cultural. São Paulo: Loyola, 1994.

HAGGET P.; CHORLEY R..J. Models in Geography, The trinity Press, Wocheter e London, 1997.

HEALEY, P. "Rational method" as a mode of policy formation and implementation in land-use policy. Environment and Planning B; Planning and design, 10, pp 19-39,1983.

HEALEY, P. Planning through Debate: The Communicative Turn in Planning Theory. The Town Planning ReviewVol. 63, No. 2 (Apr., 1992), pp. 143-162, 1992.

HEALEY, P.; KHAKEE A et alli (Eds.) Making strategic special plans: innovations in Europe. London, University College London, 1997.

HEALEY, P. The Treatment of Space and Place in the New Strategic Spatial Planning in Europe International Journal of Urban and Regional Research Volume 28.1 March 2004 45-67, 2004.

HEALEY, P. Collaborative planning in perspective in Planning Theory SAGE Publications (London, Thousand Oaks, CA and New Delhi) Vol 2(2): 101-123, 2003.

MANNHEIM, K. Sociology of Knowledge Tavistock Publication Limited, 1984.

Eletronic Magazine: Time - Technical - Territory, V.3, N.1 (2012), 147:174 ISSN: 2177-4366 
MINISTÉRIO DO PLANEJAMENTO E ORÇAMENTO INSTITUTO BRASILEIRO DE GEOGRAFIA E ESTATÍSTICA - IBGE DIRETORIA DE GEOCIÊNCIAS - DGC. Noções básicas de Cartografia, Rio de Janeiro, 128p., 1998.

MINISTÉRIO DE TRANSPORTES MT, PNLT - Plano Nacional de Logística e Transportes volume 5 - transporte e meio ambiente Tomo 1 - Relatório de Tratamento Ambiental no Setor Transporte abril/2007.

MINISTÉRIO DO MEIO AMBIENTE, MMA. Avaliação ambiental estratégica, Brasília: MMA/SQA, 92p., 2002.

SADLER, B.;VERHEEM, R., Strategic Environmental Assessment: Status, Challenges and Future Directions. Ministry of Housing, Spatial Planning and the Environment. Netherlands. p. 188,1996.

SANTOS, M. A natureza do espaço: técnica e tempo, razão e emoção. São Paulo : Hucitec, 1996.

SANTOS, M. e SILVEIRA, M. L. O Brasil. Território e sociedade no inicio do século XXI, Editora Record Ltda, 13a ed. Rio de Janeiro, 2010.

SUERTEGARAY, D. M. A. Espaço Geográfico Uno E Múltiplo Revista electrónica de geografía y ciencias sociales Universidad de Barcelona № 93, 15 de julio de 2001.

TAYLOR, D.R. Fraser. Uma Base Conceitual para a Cartografia: Novas Direções para a Era da Informação. Caderno de Textos - Série Palestras, LEMADI-DG/USP, São Paulo, v. 1, n.1, p.11-24, ago. 1994.

THERIVEL, R.; Partidário, M. R. The Pratice of Strategic Environmental

Assessment. Earthscan Publications Ltd, London, 1996.

TOURAINE, A. La Société post-industrielle. Paris, Danoel, 1996.

JEPSON, E. J. Jr. Sustainability and Planning: Diverse Concepts and Close Associations Journal of Planning Literature n.15 p.499, 2001. 